\title{
A Study of Environmental Impact and Scenario Treatment using Life Cycle Assessment Approach in Tofu Industry
}

\author{
Intan Rahmalia ${ }^{a}$, Syifa Khairun Nisa ${ }^{b}$, Vita Palupic, Aninda Putri ${ }^{d}$, I Wayan Koko Suryawan ${ }^{e^{*}}$ \\ ${ }^{a}$ Department of Environmental Engineering, Faculty of Infrastructure Planning, Universitas Pertamina, Jakarta. Email: intanrahmalia11@ gmail.com \\ bepartment of Environmental Engineering, Faculty of Infrastructure Planning, Universitas Pertamina, Jakarta. Email: syifakh22@gmail.com \\ ${ }^{c}$ Department of Environmental Engineering, Faculty of Infrastructure Planning, Universitas Pertamina, Jakarta. Email: vitapalupi99@ yahoo.com \\ ${ }^{\mathrm{d}}$ Department of Environmental Engineering, Faculty of Infrastructure Planning, Universitas Pertamina, Jakarta. Email: jsnindi31@ gmail.com \\ e Department of Environmental Engineering, Faculty of Infrastructure Planning, Universitas Pertamina, Jakarta. \\ Email: i.suryawan@universitaspertamina.ac.id
}

\begin{abstract}
One of the types of tofu industries in Indonesia is that the small-scale tofu industry was located in the East Jombor, Ketapang Village, on the Blorong River. This tofu industry, with a $1300 \mathrm{~kg} /$ day production capacity, produces liquid waste that is disposed of into the Blorong River with a BOD parameter of $2726 \mathrm{mg} / \mathrm{L}$, COD of $4972 \mathrm{mg} / \mathrm{L}$, and TSS of $388 \mathrm{mg} / \mathrm{L}$. These values greatly exceed the quality standards based on the Regional Regulation of Central Java Province Number 10 of 2004 concerning Tofu Industry. The entry of these pollutants into the Blorong River, over time, can cause water bodies to become toxic and pollute the Blorong River. Therefore, one of the efforts to protect the environmental condition of this river is to increase the efficiency of the Wastewater treatment plant and substitute the determined fuel through alternative scenarios. In the MBBR scenario, substituting diesel fuel into biomass is a type of biodiesel. It has an advantage for the fire tube boiler industry because it can reduce exhaust emissions compared to diesel. Meanwhile, the existing wastewater treatment is substituted for the MBBR unit. The choice of MBBR as a wastewater treatment unit is because it is economical, does not require large land, simple in development design, and accessible in operation and maintenance. In the second scenario (SBR), a transition of diesel fuel to LPG as a fuel input in the cooking process will result in a cleaner emission, especially on the $\mathrm{SO}_{2}$ parameter, and better because it has a higher heating value than diesel, $47.3 \mathrm{Tj} / \mathrm{Gg}$. Both scenarios are analyzed regarding the magnitude of the impact on the environment using the OpenLCA method. The result of this method from each alternative is evaluated to obtain the best scenario. In the tofu industry, the best design the resulting impact is smaller than the SBR alternative.
\end{abstract}

Keywords: Environmental impact; OpenLCA; life cycle assessment; tofu production

\section{Introduction}

The majority of Indonesian businesses have a strong interest in the tofu industry because making tofu is relatively easy, simple, and inexpensive [1]. Besides, making tofu uses simple technology with relatively low levels of resource use, such as water and raw materials. The tofu industry is dominated by small to medium-scale businesses with limited capital. However, behind the advantages of the cheap and straightforward, Tofu industry could harm the environment. In the process of making tofu, from the raw materials to tofu products, each stage of making tofu produces relatively high solid waste and liquid waste, as well as emissions released into the air. The resulting waste and air emissions are disposed of in the environment without any treatment. The environmental impact that can be felt from the absence of wastewater treatment is the damage to environmental aesthetics [2].

${ }^{*}$ Corresponding author. Tel.: +6282227774992

Jl. Teuku Nyak Arief, RT.7/RW.8, Simprug

Kec. Kebayoran Lama, Jakarta Selatan, Jakarta

Indonesia 12220
One of the tofu industries is the Industri X, located in the East Jombor, Ketapang Village, to be precise on the Blorong River. These values greatly exceed the quality standard based on Regional Regulation of the Province of Central Java Number 10 of 2004 concerning Industry Tofu. High levels of Biological Oxygen Demand (BOD) in water bodies can reduce dissolved oxygen (DO) concentrations needed for aquatic life to survive. Over time, dissolved oxygen levels can make living aquatic organisms die, and then decay occurs so that the condition of the water body becomes toxic. The liquid waste from the tofu industry is a source of water pollutants in the Blorong River.

Therefore, one of the efforts to protect this river's environmental conditions is to increase the efficiency of Waste Water Tteatment Plant (WWTP) and substitute the determined fuel by providing alternative scenarios by Life Cycle Assessment (LCA). LCA has been widely applied in Indonesia to determine industrial activities' environmental impact [3, 4, 5]. This study aims to determine the environmental impact and update the tofu industry management with LCA. 


\section{Method}

LCA is a method to evaluate the potential environmental impacts of the life cycle by calculating the inputs such as natural resources demand and outputs such as emissions and solid waste that can impact ecological aspects such as climate change, ecotoxicity, etc. [6]. Generally, the LCA method consists of four steps: goal and scope, life cycle inventory analysis, life cycle impact assessment, and interpretation [7].

According to Sala et al. [7], this method aims to define the intended application and determine both spatial and temporal boundaries so the study can focus on environmental assessment's important issues.

The goal and scope ensuring the choices of functional unit, system boundaries, identification of parametric quality requirement, and the intended audience is already made up.

\section{Goals:}

- Finding the best scenario by considering aspects of land requirements, economic, aesthetic, environmental health, and technology.

- The effluent can meet the quality standard threshold criteria for the Central Java Provincial Regulation Number 10 of 2004 concerning Tofu Industry.

- Reducing the impact of pollution from industrial activity processes.

\section{Scopes:}

- Tofu made from soybean seeds

- The dregs of X Tofu Industry are \pm 30 sacks to produce \pm 60 barrels of tofu.

- The need for soybeans is $\pm 840 \mathrm{~kg} /$ day with a capacity of $1300 \mathrm{~kg} /$ day.

- The need for diesel (for cooking) is $\pm 5-10 \mathrm{~L} /$ day.

- The amount of wastewater is $35 \mathrm{~m}^{3} /$ day.

- System Limits: Gate to Gate.

- Allocation and System Expansion: based on mass and volume, and based on other rules (frequency and substance content).

- Data Quality Requirements: Water requirements, the number of soybeans, acid and $\mathrm{CaSO}_{4}$ needs, and fuel requirements (diesel).

As stated in Life Cycle Inventory (LCI) is one of the steps in the LCA method that gave a result in a flow model by collecting and calculating all the input and output data for each process. By the limitation of collection data, the calculation of industrial tofu can be made by using parametric quality from journal literature.

\section{Result and Discussion}

\subsection{The existing treatment method}

The existing WWTP that has been applied to processing the wastewater from the tofu process uses anaerobic-aerobic technology. The resulting wastewater will be flowed into the bar screen to filter the coarse fractions and continue to the equalization basin through trenches in the factory. The residence time of water in the equalization tank is 37.8 hours or 1.5 days, with the volume capacity of the storage tank is $63 \mathrm{~m}^{3}$. Through this stage, $11 \%$ of Total Suspended Solid (TSS) is removed. Then, after going through the process at the equalization stage, the wastewater is flowed into an anaerobic tank to remove the organic content in the wastewater. With anaerobic tanks' capacity is $300 \mathrm{~m} 3$, it can accommodate wastewater with a residence time of 7,5 days. Several organic materials were removed in this process, namely $65 \%$ TSS, $95.2 \%$ BOD, 92\% COD. The type of anaerobic tank is the Anaerobic Baffled Reactor (ABR). In the anaerobic removal process, the activated sludge has been formed through anaerobic fermentation process of anaerobic bacteria $[8,9]$.

This activated sludge plays an essential role in removing the organic material that takes place in the reactor. The activated sludge that settles in the bottom of the reactor will be recirculated in the reactor so that the organic removal process can achieve maximum efficiency. The by-product of the anaerobic process that occurs in the reactor is methane gas $\left(\mathrm{CH}_{4}\right)$. Then, the methane gas is flowed into the flare pipe to be burned so that it doesn't smell. Also, methane gas $\left(\mathrm{CH}_{4}\right)$ has the potential to be used as an alternative fuel or biogas, which can be distributed to local residents' homes or to the production process in the tofu factory itself or lighting the area around the factory location. Due to the lack of facilities to distribute the gas flow, it isn't yet been implemented. The effluent from ABR will flow into the aeration tank. In this reactor, dissolved oxygen in the wastewater will encourage the degradation of organic material in the wastewater by aerobic bacteria, which will continue to produce activated sludge. The residence time of wastewater in the reactor is 3.6 hours with a tank capacity of $6 \mathrm{~m}^{3}$. The organic material content was removed at this processing stage, namely BOD of 56\%, TSS of $51.5 \%$, COD of $48.9 \%$. After going through the aeration treatment process, the wastewater will then be flowed into the outlet tank or final tank and continue to the water body or the Blorong river.

The maximum processing results and the uncomplex unit operation in the anaerobic-aerobic treatment method make the treatment a standard method for most industries to treat their wastewater, even though the processing time is longer than other processing methods. The existing WWTP has been operating for 14 years since 1996. This WWTP was not built when the factory was built for the first time. Previously, the community had protested to the factory because of the pollution from the discharge wastewater production that polluted the water river. However, for the past 14 years, the company has started to be concerned about their behaviour to damage the environment. A WWTP was built along with the employment of human resources which could operate it.

Based on the processing flow, the overall processing unit performance is obtained for each pollutant parameter obtained through Fibria research [10], described in Table 1 and Table 2. 
Table 1. The removal characteristic in existing WWTP

\begin{tabular}{|c|c|c|c|c|c|c|c|}
\hline \multirow[b]{2}{*}{ No } & \multirow[b]{2}{*}{ Parameter } & \multirow{2}{*}{$\begin{array}{l}\text { Influent } \\
\text { WWTP } \\
\text { (Output } \\
\text { Industry) }\end{array}$} & \multirow[b]{2}{*}{$\begin{array}{l}\text { Effluent } \\
\text { WWTP }\end{array}$} & \multirow[b]{2}{*}{$\begin{array}{c}\text { Load } \\
\text { (kg/day) }\end{array}$} & \multicolumn{2}{|c|}{ Quality Standard } & \multirow{2}{*}{$\begin{array}{c}\text { Removal } \\
\text { Efficiency } \\
(\%)\end{array}$} \\
\hline & & & & & $\begin{array}{l}\text { Maximum } \\
\text { Content }\end{array}$ & $\begin{array}{c}\text { Maximum } \\
\text { Pollution Load } \\
\text { (kg/ton) }\end{array}$ & \\
\hline \multicolumn{8}{|c|}{ PHYSIC } \\
\hline 1. & Temperature & $43.1 \mathrm{oC}$ & 36.9 oC & - & 38 & - & - \\
\hline 2. & TSS & $\begin{array}{c}388 \\
\mathrm{mg} / \mathrm{L}\end{array}$ & $\begin{array}{c}62 \\
\mathrm{mg} / \mathrm{L}\end{array}$ & 2.170 & 100 & 2 & $87 \%$ \\
\hline \multicolumn{8}{|c|}{ CHEMICAL } \\
\hline 3. & BOD & $\begin{array}{l}2726 \\
\mathrm{mg} / \mathrm{L}\end{array}$ & $\begin{array}{c}57.6 \\
\mathrm{mg} / \mathrm{L}\end{array}$ & 2.016 & 150 & 3 & $97.80 \%$ \\
\hline 4. & COD & $\begin{array}{l}4972 \\
\mathrm{mg} / \mathrm{L}\end{array}$ & $\begin{array}{l}203.2 \\
\mathrm{mg} / \mathrm{L}\end{array}$ & 7.112 & 275 & 5.5 & $95 \%$ \\
\hline 5. & $\mathrm{pH}$ & 5.51 & 7.06 & - & $6.0-9.0$ & - & - \\
\hline
\end{tabular}

Table 2. The removal result from each unit at the existing treatment

\begin{tabular}{|c|c|c|c|c|c|c|c|c|c|c|c|}
\hline \multirow{3}{*}{ Parameter } & \multirow{2}{*}{ Influent } & \multicolumn{2}{|c|}{ Bar Screen } & \multicolumn{2}{|c|}{ Equalization Tank } & \multicolumn{2}{|c|}{ Anaerobic Tank } & \multicolumn{2}{|c|}{ Aerobic Tank } & \multirow{2}{*}{ Outlet } & \multirow{2}{*}{$\begin{array}{l}\text { Quality } \\
\text { Standard }\end{array}$} \\
\hline & & Efficiency & Effluent & Efficiency & Effluent & Efficiency & Effluent & Efficiency & Effluent & & \\
\hline & $(\mathrm{mg} / \mathrm{L})$ & $(\%)$ & $(\mathrm{mg} / \mathrm{L})$ & $(\%)$ & $(\mathrm{mg} / \mathrm{L})$ & $(\%)$ & $(\mathrm{mg} / \mathrm{L})$ & $(\%)$ & $(\mathrm{mg} / \mathrm{L})$ & $(\mathrm{mg} / \mathrm{L})$ & $(\mathrm{mg} / \mathrm{L})$ \\
\hline TSS & 388 & 0 & 388 & 11 & 345.32 & 65 & 120.86 & 51.5 & 62.24 & 62 & 100 \\
\hline BOD & 2726 & 0 & 2726 & 0 & 2726 & 95.2 & 130.85 & 56 & 57.57 & 57.6 & 150 \\
\hline COD & 4972 & 0 & 4972 & 0 & 4972 & 92 & 397.76 & 48.9 & 203.24 & 203 & 275 \\
\hline $\mathrm{pH}$ & 5.51 & 5.92 & 5.51 & - & 6.42 & - & 6.92 & - & 7.06 & 7.06 & $6.0-9.0$ \\
\hline
\end{tabular}

\subsection{Moving Bed Biofilm Reactor (MBBR) treatment method-Scenario 1}

The principle of the Moving Bed Biofilm Reactor (MBBR) is the activated sludge process with the addition of media and the presence of an aeration process in the reactor [11]. The MBBR method is included in the attached growth reactor type because of the media's addition into the reactor. It will encourage the biological growth process of microbes with suspended and attached cultures. The MBBR has the advantages: easy to maintain and requires less land area. The results of the calculation of the removal efficiency scenario with the MBBR unit can be seen in Table 3.

\subsection{Sequencing Batch Reactor (SBR) treatment method- Scenario 2}

SBR has the advantage of the need for the area. The SBR unit does not require a large area because it is compact while still providing high efficiency in treating liquid waste and making unit costs cheaper than the standard activated sludge technology. SBR consists of five processing phases and is carried out sequentially as follows:

a. Fill in the phase when the volume of wastewater enters the reactor and mixes with the sedimented biomass. After the tank reaches its maximum capacity, the process will proceed to the next stage. The time given for each stage depends on the purpose of wastewater treatment. The typical time for the fill stage is two to four hours. In a two-tank system, the time required to fill is the same as the amount of reacting, settle, decant, and idle time so that when one tank is in the fill stage, the other tank can complete the cycle. Anoxic conditions at the fill stage are recommended to achieve a good condition for settling organisms [12].

b. React is a phase where the process occurs is the same as in the aeration of the activated sludge process. Under suitable environmental conditions, biomass will eat the substrate. During the reaction stage, the mixing unit and the aeration unit are actively used, and no more wastewater enters this stage, and there is a removal of the carbonaceous BOD. Besides, it is necessary to determine the duration of aeration removal so that nitrification removal can occur.

c. Settle is a phase where the process is the same as the sedimentation unit or clarification unit in the activated sludge process. This process causes the solid to sink and separate from the water.

d. The draw is the phase where water that has been cleaned is disposed of as effluent.

e. Idle is the phase that occurs between the draw-and-fill phases, and it is used to provide time before the switching process. This stage can be on short-period or long-period depending on the amount of discharge of treated wastewater. This phase can be eliminated if the wastewater has a high release. Conversely, if the wastewater has a low release, this stage will take a long time so that the sludge turns anaerobic.

The results of the calculation of the removal efficiency scenario with the SBR unit can be seen in Table 4. 
Table 3. The removal result from each unit at MBBR treatment

\begin{tabular}{|c|c|c|c|c|c|c|c|c|c|}
\hline \multirow{2}{*}{ Parameter } & \multirow{2}{*}{ 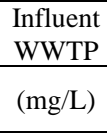 } & \multicolumn{2}{|c|}{ Bar Screen } & \multicolumn{2}{|c|}{ Equalization Tank } & \multicolumn{2}{|c|}{ MBBR } & \multirow{2}{*}{$\begin{array}{l}\begin{array}{l}\text { Effluent } \\
\text { WWTP }\end{array} \\
(\mathrm{mg} / \mathrm{L})\end{array}$} & \multirow{2}{*}{$\begin{array}{c}\text { Quality } \\
\text { Standard } \\
(\mathrm{mg} / \mathrm{L})\end{array}$} \\
\hline & & Efficiency & $\begin{array}{c}\begin{array}{c}\text { Effluent } \\
(\mathrm{mg} / \mathrm{L})\end{array} \\
\end{array}$ & Efficiency & $\begin{array}{c}\text { Effluent } \\
(\mathrm{mg} / \mathrm{L})\end{array}$ & Efficiency & $\begin{array}{c}\text { Effluent } \\
(\mathrm{mg} / \mathrm{L})\end{array}$ & & \\
\hline TSS & 388 & 0 & 388 & $11 \%$ & 345.32 & $73 \%$ & 93.24 & 93.24 & 100 \\
\hline BOD & 2726 & 0 & 2726 & 0 & 2726 & $80 \%$ & 545.2 & 545.2 & 150 \\
\hline COD & 4972 & 0 & 4972 & 0 & 4972 & $82 \%$ & 895 & 894.96 & 275 \\
\hline
\end{tabular}

Table 4. The removal result from each unit at SBR treatment

\begin{tabular}{|c|c|c|c|c|c|c|c|c|c|}
\hline \multirow{2}{*}{ Parameter } & \multirow{2}{*}{$\begin{array}{l}\begin{array}{l}\text { Influent } \\
\text { WWTP }\end{array} \\
(\mathrm{mg} / \mathrm{L})\end{array}$} & \multicolumn{2}{|c|}{ Bar Screen } & \multicolumn{2}{|c|}{ Equalization Tank } & \multicolumn{2}{|c|}{ SBR } & \multirow{2}{*}{$\begin{array}{l}\text { Effluent } \\
\text { WWTP } \\
(\mathrm{mg} / \mathrm{L})\end{array}$} & \multirow{2}{*}{$\begin{array}{c}\text { Quality } \\
\text { Standard } \\
(\mathrm{mg} / \mathrm{L})\end{array}$} \\
\hline & & Efficiency & $\begin{array}{c}\begin{array}{c}\text { Effluent } \\
(\mathrm{mg} / \mathrm{L})\end{array} \\
\end{array}$ & Efficiency & $\begin{array}{c}\begin{array}{c}\text { Effluent } \\
(\mathrm{mg} / \mathrm{L})\end{array} \\
\end{array}$ & Efficiency & $\begin{array}{c}\text { Effluent } \\
(\mathrm{mg} / \mathrm{L})\end{array}$ & & \\
\hline TSS & 388 & 0 & 388 & $11 \%$ & 345.3 & $98 \%$ & 6.906 & 6.91 & 100 \\
\hline BOD & 2726 & 0 & 2726 & 0 & 2726 & $98 \%$ & 54.52 & 54.52 & 150 \\
\hline $\mathrm{COD}$ & 4972 & 0 & 4972 & 0 & 4972 & $99 \%$ & 49.72 & 49.72 & 275 \\
\hline
\end{tabular}

\subsection{Life Cycle Impact Assessment (LCIA) of existing condition}

The LCIA is a step of classifying the emission from product production into impact categories, and then these categories will be compared by characterizing it into common units [7]. The comparison of common units of all categories can be done by converting the data using some of the assumptions from the literature that can be seen in Table 3 and Table 4.

The inventory analysis results were reviewed further using an impact assessment of the product or activity according to specific indicators. This assessment using the 2013 Environmental Product Declaration (EPD) assessment method available on the OpenLCA application. The following is a table of the resulting environmental impact categories in Table 5.

a. Acetic Acid $\left(\mathrm{CH}_{3} \mathrm{COOH}\right)$. The need for acetic acid used during production is influenced by the amount of soybean raw material used in the production of tofu. The $\mathrm{X}$ tofu industry needs $840 \mathrm{~kg}$ of soybeans to produce $1300 \mathrm{~kg}$ of tofu per day [13] showed that using $144 \mathrm{~kg}$ of soybean raw materials and supporting materials in the form of $1 \mathrm{~L}$ of vinegar acid water could produce $260 \mathrm{~kg}$ of tofu per day.

Table 5. Input and output value of existing scenario

\begin{tabular}{ccc}
\hline Material & Unit & Quantity \\
\hline Input Material & & \\
\hline Acetic acid & $\mathrm{kg} / \mathrm{day}$ & 6.125 \\
Energy, unspecified & $\mathrm{MJ} / \mathrm{day}$ & 373 \\
Transformation, to agriculture, mosaic & $\mathrm{ha} / \mathrm{day}$ & 1.292 \\
Water, well, in ground & $\mathrm{m}^{3} / \mathrm{day}$ & $3,024,000$ \\
\hline Output Material & & \\
\hline BOD5, Biological Oxygen Demand & $\mathrm{kg} / \mathrm{day}$ & 174182.4 \\
Carbon dioxide, fossil & $\mathrm{kg} / \mathrm{day}$ & 27.628 \\
$\mathrm{COD}$, Chemical Oxygen Demand & $\mathrm{kg} / \mathrm{day}$ & 614476.8 \\
$\mathrm{NO}_{2,}$ Nitrogen dioxide & $\mathrm{kg} / \mathrm{day}$ & 0.00768 \\
Sulfur dioxide & $\mathrm{kg} / \mathrm{day}$ & 0.0479 \\
Tofu & $\mathrm{kg} / \mathrm{day}$ & 1300 \\
Waste, unspecified $^{2}$ & $\mathrm{~kg} / \mathrm{day}$ & 390 \\
\hline
\end{tabular}

The need for acetic acid to make tofu from $840 \mathrm{~kg}$ of soybean raw materials is 6.125 Liters.

b. Solar (Unspecified energy). Solar is the fuel used in the cooking and maturation process of soybeans before being processed into tofu. Then diesel is used to cook and ripen $840 \mathrm{~kg}$ of soybeans is 10 litres per day [14]. The amount of diesel emission released was obtained by multiplying between the amount of diesel used and the diesel emission factor of $37.3 \mathrm{MJ} / \mathrm{Litre}$.

c. Soybean (transformation, to agriculture, mosaic). Soybean is an input material used in the tofu production process. The soybean mass value needs to be transformed into a unit area to be input into the LCA application. Based on the results of a study on the distribution pattern of soybean productivity in Central Java Province by district/city, X Regency has soybean productivity 14-11 quintals per hectare [15]. The data on average soybean productivity will be used as an indicator to estimate the acreage of soybean gardens that can produce $1300 \mathrm{~kg}$ of soybeans. So, the area of the soybean plantation obtained 1.292 ha.

d. Water Discharge (water, well, in the ground). The water discharge used in processing soybeans into tofu is $3,024,000 \mathrm{~m}^{3} / \mathrm{day}$.

e. BOD) and COD parameters are parameters used in determining the quality of wastewater because they both have characteristics in knowing the presence of pollution induction from a decrease in the amount of dissolved oxygen.

f. Sulfur dioxide $\left(\mathrm{SO}_{2}\right)$ and Nitrogen dioxide $\left(\mathrm{NO}_{2}\right)$ are exhaust gases from the combustion of diesel fuel in a soybean grinding machine in the $\mathrm{X}$ Industrial tofu production. The amount of emission $\mathrm{SO} 2$ that it produces is determined by calculating the fuel requirement and the default emission factor for diesel fuel. In the study of the analysis of emission load estimation $\mathrm{SO}_{2}$ and $\mathrm{NO}_{\mathrm{X}}$ from industrial activities in Karang Pilang Surabaya, it was stated that the SO emission factor from the use of diesel fuel was 4.79 $\mathrm{kg} / 1000 \mathrm{~L}$ and the emission factor $\mathrm{NO}_{2}$ was 0.768 $\mathrm{kg} / 1000 \mathrm{~L}$ [16]. The literature data are used to estimate the total emissions resulting from the use of diesel in tofu production is $0.0479 \mathrm{~kg} \mathrm{SO} \mathrm{S}_{2}$ and $0.00768 \mathrm{~kg} \mathrm{NO}_{2}$. 
Table 6. Result of impact analysis of existing scenario

\begin{tabular}{ccc}
\hline Environmental Impact & Score & Unit \\
\hline Abiotic Depletion & 373 & $\mathrm{MJ}$ \\
Global Warming & 27.628 & $\mathrm{~kg} \mathrm{CO}_{2}$ \\
Eutrophication & 135,185 & $\mathrm{~kg} \mathrm{PO}_{4}$ \\
Acidification & 0.05328 & $\mathrm{~kg} \mathrm{SO}_{2}$ \\
Photochemical Oxidation & 0.00251 & $\mathrm{~kg} \mathrm{C}_{2} \mathrm{H}_{4}$ \\
\hline
\end{tabular}

After inputting data into the OpenLCA application based on the calculation of the input and output values above, the resulting impact will be automatically calculated. The overall results of the impact assessment of the input and output data that have been carried out can be seen in Table 6 .

Based on the impact assessment using the OpenLCA application with the 2013 EPD method, the existing conditions have several impacts, while the most impacting is global warming of $27.628 \mathrm{~kg} \mathrm{CO}_{2}$. Based on Table 6 , the existing conditions' impact is classified as significant, so a scenario is created to reduce the negative impact of the environment. This scenario substitutes the use of diesel fuel in the existing conditions to the use of biomass. Also, this scenario uses the MBBR unit to treat wastewater generated from tofu production.

In this scenario, the choice to substitute diesel fuel is because diesel has a high enough contribution to global warming. In one of the efforts to minimize global warming, the Indonesian government is committed to using renewable energy resources as a substitute for conventional fuels. The potential for renewable energy that can be utilized is biomass. The type of biomass used in this scenario is biodiesel. The use of biodiesel has an advantage for the fire tube boiler industry because it can reduce exhaust emissions compared to diesel/diesel oil. Pollutant gas emissions decrease with the increase in the biodiesel content in the mixture [17]. However, the amount of use of biodiesel is more than the amount of use of diesel. Biodiesel has a calorific value of 5-13\% lower than diesel oil. When applied to the fuel system, more fuel is injected to achieve combustion stoichiometry to increase fuel consumption [17]. The amount of biomass used is $1-2 \%$ more than the use of diesel as fuel [18]. Emissions resulting from burning biodiesel include $\mathrm{CO}_{2}, \mathrm{CH}_{4}, \mathrm{~N}_{2} \mathrm{O}$.. $\mathrm{CO}_{2}$ emissions produced if biodiesel is burned are not included in total emissions or are considered excluding emissions, while $\mathrm{CH}_{4}$ and $\mathrm{N}_{2} \mathrm{O}$ emissions are calculated as emissions [19]. The following is the number of emissions released by the biodiesel type biomass:

Input

Biodiesel $=$ The amount of diesel, used $\times 2 \%$

$$
\begin{aligned}
& =373 \mathrm{MJ} \times 2 \% \\
& =380.5 \mathrm{MJ}
\end{aligned}
$$

Output

$$
\begin{aligned}
N_{2} O \text { Emission } & =\sum F C \times C E F \times N C V \\
& =380.5 \mathrm{MJ} \times 4 \mathrm{~kg} / \mathrm{TJ} \times 1000000 \mathrm{MJ} / \mathrm{TJ} \\
& =0.001522 \mathrm{~kg}
\end{aligned}
$$

$$
\begin{aligned}
\mathrm{CH}_{4} \text { Emission } & =\sum F C \times C E F \times N C V \\
& =380.5 \mathrm{MJ} \times 30 \mathrm{~kg} / \mathrm{TJ} \times 1000000 \mathrm{MJ} / \mathrm{TJ} \\
& =0.011415 \mathrm{~kg}
\end{aligned}
$$

where

$\sum \mathrm{FC}$ is the amount of fossil fuel used (mass /volume)

$\mathrm{NCV}$ is Net Calorific Volume (energy content) value per unit mass or volume of fuel

$\mathrm{CEF}$ is the carbon emission factor

\subsection{Life Cycle Impact Assessment (LCIA) of MBBR scenario}

This scenario also uses the MBBR unit to treat wastewater generated from tofu production. The choice of MBBR as a wastewater treatment unit is because it is economical, does not require large land, simple in development design, and easy to operate and maintain. In general, tofu industry players lack knowledge about the tofu wastewater treatment process, so that tofu industry players tend to choose simple tofu wastewater treatment. However, the allowance for MBBR units still exceeds the quality standard of the Central Java Provincial Regulation Number 10 of 2004 concerning the Tofu Industry. The following is the number of COD and BOD generated through the MBBR processing unit:

$$
\begin{aligned}
B O D & =\text { effluent BOD processing unit MBBR } \times \text { discharge } \\
& =545.2 \mathrm{mg} / \text { liter } \times 3,024,000 \mathrm{~m}^{3} / \text { day } \times 10^{-3} \\
& =1,648,684.8 \mathrm{~kg} \\
C O D & =\text { effluent COD processing unit MBBR } \times \text { discharge } \\
& =894.96 \times 3,024,000 \mathrm{~m}^{3} / \mathrm{day} \times 10^{-3} \\
& =2,706,359.04 \mathrm{~kg}
\end{aligned}
$$

Table 7 are the inputs and outputs of MBRR scenario.

Table 7. Input and output value MBBR scenario

\begin{tabular}{ccc}
\hline Material & Unit & Quantity \\
\hline Technical Input & & \\
\hline Energy, unspecified & $\mathrm{kg} /$ day & 6.125 \\
Transformation, to agriculture, mosaic & $\mathrm{Mj} /$ day & 380.5 \\
Water, well, in ground & $\mathrm{h} /$ day & 1.292 \\
Technical Output & $3,024,000$ \\
BOD5, Biological Oxygen Demand & $\mathrm{kg} / \mathrm{day}$ & $1,648,684.8$ \\
Carbon dioxide, fossil & $\mathrm{kg} / \mathrm{day}$ & 0 \\
COD, Chemical Oxygen Demand & $\mathrm{kg} / \mathrm{day}$ & 2706359.04 \\
Nitrogen dioxide & $\mathrm{kg} / \mathrm{day}$ & 0.001522 \\
Methane & $\mathrm{kg} / \mathrm{day}$ & 0.011415 \\
Tofu & $\mathrm{kg} / \mathrm{day}$ & 1.3 \\
Waste, unspecified & $\mathrm{kg} / \mathrm{day}$ & 390 \\
\hline
\end{tabular}


Table 8. Result of impact analysis of MBBR scenario

\begin{tabular}{ccc}
\hline Environmental Impact & Score & Unit \\
\hline Abiotic Depletion & 0 & $\mathrm{MJ}$ \\
Global Warming & 0.722 & $\mathrm{~kg} \mathrm{CO}_{2}$ \\
Eutrophication & 59539 & $\mathrm{~kg} \mathrm{PO}_{4}$ \\
Acidification & 0 & $\mathrm{~kg} \mathrm{SO}_{2}$ \\
Photochemical Oxidation & 0.594 & $\mathrm{~kg} \mathrm{C}_{2} \mathrm{H}_{4}$ \\
\hline
\end{tabular}

Based on the input and output of the tofu-making process, an impact analysis (impact assessment) using the EPD 2013 method was obtained. This scenario succeeded in reducing global warming, but there was an increase in the eutrophication impact of $59,539 \mathrm{~kg} \mathrm{PO}_{4}$. Table 8 is the impact on the environment in the scenario MBBR:

\subsection{Life Cycle Impact Assessment (LCIA) SBR scenario}

The conversion of diesel fuel to LPG as a source of heat energy in the boiling process of soybeans is part of the environmental recovery scenario for emissions produced in the tofu production process. This scenario was chosen to consider environmental aspects. Reducing greenhouse gas (GHG) emissions from burning diesel fuel is the main scope of scenario studies for environmental aspects. The proportion of $\mathrm{CO}_{2}$ exhaust emissions is the largest emission resulting from diesel use in the $\mathrm{X}$ industrial tofu production process and partly by SOx and NOx gases. The GHG emission reduction target is based on Presidential Regulation Number 71 of 2011, which is $26 \%$ in 2020 in the $\mathrm{CO}_{2}$ exhaust element.

The use of LPG fuel is a processed product from fossil energy. The combustion process carried out on the fuel will contribute to atmospheric pollutants with different types and amounts of content. LPG and Solar are the two fuels that have additional combustion capabilities according to their calorific value. Still, the combustion capability is not always in line with exhaust gas as a byproduct produced. Solar has a $43.3 \mathrm{TJ} / \mathrm{Gg}$ and LPG heating value of $47.3 \mathrm{TJ} / \mathrm{Gg}$ [20]. However, this does not instantly mean that $\mathrm{CO} 2, \mathrm{SOx}$, and $\mathrm{NOx}$ exhaust gases are in small amounts compared to LPG. According to Suarma [21], using LPG as a fuel input in the cooking process will result in cleaner emissions, especially in the $\mathrm{SO}_{2}$ parameter.

Besides using alternative fuels in making tofu, it is necessary to treat wastewater generated from the $\mathrm{X}$ industrial tofu processing activity. The second scenario using the Sequencing Batch Reactor (SBR) as a wastewater treatment unit by considering the small area requirement. Even in a single basin, there are already several processing stages of wastewater treatment in general. The emission from the wastewater produced can be reduced, and it is known based on the efficiency of the unit used. Furthermore, inputting parameter data Liquid waste in the openLCA application is carried out by converting $\mathrm{mg} / \mathrm{L}$ to $\mathrm{kg}$, then calculations will be outlined in Table 9.
Table 9. Input and output value SBR scenario

\begin{tabular}{|c|c|c|}
\hline Material & Unit & Quantity \\
\hline \multicolumn{3}{|c|}{ Technical Input } \\
\hline Acetic acid & $\mathrm{kg} /$ day & 6.125 \\
\hline Energy, unspecified & L/day & 14.647 \\
\hline Transformation, to agriculture, mosaic & ha/day & 1.292 \\
\hline Water, well, in ground & $\mathrm{m}^{3} /$ day & $3,024,000$ \\
\hline \multicolumn{3}{|c|}{ Technical Output } \\
\hline BOD5, Biological Oxygen Demand & $\mathrm{kg} /$ day & 164868.48 \\
\hline Carbon dioxide, fossil & $\mathrm{kg} /$ day & 5.678 \\
\hline COD, Chemical Oxygen Demand & $\mathrm{kg} /$ day & 150353.28 \\
\hline Nitrogen dioxide & $\mathrm{kg} /$ day & 0.00033 \\
\hline Sulfur dioxide & $\mathrm{kg} /$ day & 0.0016 \\
\hline Tofu & $\mathrm{kg} /$ day & 1.3 \\
\hline Waste, unspecified & $\mathrm{kg} /$ day & 390 \\
\hline
\end{tabular}

Table 10. Result of impact analysis of MBBR scenario

\begin{tabular}{ccc}
\hline Environmental Impact & Score & Unit \\
\hline Abiotic Depletion & 0.50532 & $\mathrm{MJ}$ \\
Global Warming & 5.67890 & $\mathrm{~kg} \mathrm{CO}_{2}$ \\
Eutrophication & 3307.772 & $\mathrm{~kg} \mathrm{PO}_{4}$ \\
Acidification & 0.00183 & $\mathrm{~kg} \mathrm{SO}_{2}$ \\
Photochemical Oxidation & 0.0000861639 & $\mathrm{~kg} \mathrm{C}_{2} \mathrm{H}_{4}$ \\
\hline
\end{tabular}

After inputting all the data into the openLCA application, the impact analysis will load automatically by determining a specific impact assessment method. In this case, the method used is the 2013 EPD method as shown in Table 10.

\section{Conclusion}

The tofu production in industrial tofu $\mathrm{X}$ produces 373 MJ abiotic depletion, $27.628 \mathrm{~kg}-\mathrm{CO}_{2}$ that contributes to global warming, $135,185 \mathrm{~kg}-\mathrm{PO}_{4}$ that contributes to eutrophication, $0.053 \mathrm{~kg}-\mathrm{SO}_{2}$ that contribute to

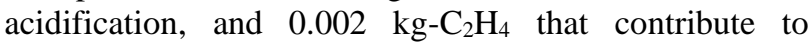
photochemical oxidation. Based on mass balance calculation, the second scenario can meet the standard quality of Central Java Provincial Regulation Number 10 of 2004 concerning the Tofu Industry. The best scenario chosen can be determined by normalizing, weighting the result by identifying the significant issue. The best recommendation of waste treatment for the industry is using the first scenario, which is by adding MBBR for the wastewater treatment and substitute the diesel fuel with the alternate biomass. This scenario has more advantages than the second scenario in reducing the environmental aspect's impact, and the reduction can be high up to $373 \mathrm{MJ}$ for abiotic depletion, $26.906 \mathrm{~kg}-\mathrm{CO}_{2}$ that contribute to global warming and $0.591 \mathrm{~kg}-\mathrm{C}_{2} \mathrm{H}_{4}$ that contribute to photochemical oxidation. 


\section{References}

[1] Simanjuntak N A M B, Zahra, NL., Suryawan, IWK.. Tofu Wastewater Treatment Planning with Anaerobic Baffled Reactor (ABR) and Activated Sludge Application. Jurnal Ilmu Alam dan Lingkungan, 2021:12(1):21-27.

[2] Sofiyah ES. Suryawan, IWK. Cultivation of Spirulina platensis and Nannochloropsis oculata for nutrient removal from municipal wastewater. Rekayasa, 2021:14(1):93-97.

[3] Fauzi AM., Rusli MS., Rustiadi E. A Study of the Smallholder Coffee Agroindustry Sustainability Condition Using the Life Cycle Assessment Approach in Bengkulu Province, Indonesia. Journal of Ecological Engineering, (2019):20(6).

[4] Masayu R, Masruri A, Putra RA. Analysis Of Environmental Impact With The Life Cycle Assessment (LCA) Method On Tofu Production. International Journal of Science, Technology \& Management, 2020:1(4):428-43

[5] Kurniawati SD, Supartono W, Suyantohadi A.. Life cycle assessment on a small scale tofu industry in Baturetno villageBantu District-Yogyakarta. In IOP Conference Series: Earth and Environmental Science. 2019:365: 012066

[6] Suryawan IWK, Rahman A, Septiariva IY, Suhardono S, Wijaya I M W. Life Cycle Assessment Of Solid Waste Generation During And Before Pandemic Of Covid-19 In Bali Province. Journal Of Sustainability Science And Management, 2021:16(1):11-21.

[7] Sala S, Reale F, Cristobal-Garcia J, Marelli ., Pant R Life Cycle Assessment for The Impact Assessment of Policies. Europian Union. 2016:

[8] Suryawan IWK, Prajati G, Afifah A S, Apritama MR, Adicita, Y. Continuous piggery wastewater treatment with anaerobic baffled reactor (ABR) by bio-activator effective microorganisms (EM4). Indonesian Journal of Urban And Environmental Technology, 2019:3(1):1-12

[9] Afifah AS, Apritama MR, Adicita Y, Septiariva IY. Enhanced Effluent Quality of Anaerobic Baffled Reactor (ABR) With Ozone and Aerobic Activated Sludge for Livestock Wastewater Treatment. EPI International Journal of Engineering, 2020:3(2):108-112.

[10]Fibria K. Kajian Teknis Pengolahan Limbah Padat dan Cair Industri Tahu. Program Studi Megister Universitas Diponegoro; 2007.
[11] Alisa N, Purnomo YS. Penurunan Kandungan Polutan Pada Air Limbah Industri Tempe Menggunakan Moving Bed Biofilm Reactor (MBBR). EnviroUS, 2020:1(1):42-47.

[12] Irvine R L, Busch A W. Sequencing batch biological reactors: an overview. Journal (Water Pollution Control Federation), 1979:235243.

[13]Gunanda R. Analisis Agroindustri Kedelai di Kecamatan Seberida Kabupaten Indragiri Hulu Privinsi Riau. Jurnal Agribisnis, 2016:18(2):100-117.

[14] Kaswinarni F. Kajian Teknis Pengolahan Limbah Padat dan Cair Industri Tahu: Studi Kasus Industri Tahu Tandang Semarang, Sederhana dan Gagak Sipat Boyolali. Universitas Diponegoro; 2007.

[15] Arnanda F, Kriswanto Y, Izzatun I, Nurlita D, Fajriyani A, Utami TW. Pemodelan Ketahanan Pangan Kedelai (Glysine Soya Max (Lenus\&Merril)) Di Provinsi Jawa Tengah Dengan Pendekatan Spatial Regression. Jurnal Statistika Universitas Muhammadiyah Semarang, 2015:3(1).

[16]Handriyono R E. Kusuma MN. Estimasi Beban Emisi SO2 dan NOx Dari Kegiatan Industri Di Karang Pilang Surabaya. Seminar Nasional Sains dan Teknologi Terapan V, 2017:A19-A24.

[17] Komariah L N. Analisis Efek Penggunaan Biodiesel Sebagai Bahan Bakar Terhadap Kinerja Fire Tube Boiler. Universitas Sriwijaya: 2015

[18] Afriyadi A E. Mau Dipakai untuk Bahan Bakar, Biodiesel Sedikit Boros. Detikfinance. https://finance.detik.com/energi/d4191308/mau-dipakai-untuk-bahan-bakar-biodiesel- sedikit-boros. (2018). (Accessed on 1 December 2020)

[19]Kementerian Industri Republik Indonesia. Draft Petunjuk Teknis Perhitungan Emisi Gas Rumah Kaca (GRK) di Sektor Industri. Jakarta; 2012.

[20]Nugrahayu Q. Penentuan Faktor Emisi Spesifik Dari Sektor Transportasi Dan Industri Untuk Estimasi Tapak Karbon Dan Pemetaannya Di Kabupaten Sumenep jawa Timur (Doctoral dissertation, Institut Technology Sepuluh Nopember); 2015

[21] Suarna E. Program'konversi Minyak Tanah Ke Lpg'sebagai Suatu Tehnik Pengurangan Emisi. Jurnal Rekayasa Lingkungan, 2010:6(2):215-221. 